Alexander V. Pigin

Petrozavodsk State University

Petrozavodsk, Russia

av-pigin@yandex.ru

\title{
HAGIOGRAPHIC WRITINGS IN THE OLD BELIEVER CONTROVERSIES OVER 'THE SUICIDAL DEATH' AT THE END OF THE SEVENTEENTH AND THE EIGHTEENTH CENTURIES (PETER PROKOP'EV'S MESSAGE TO DANIIL VIKULIN)*
}

The history of the Old Believer self-immolations and related to them the Old Believer controversial writings at the end of the seventeenth and the eighteenth centuries is a rather well-researched topic in the Russian humanities. From the nineteenth century to the beginning of the twenty first a number of historians and philologists have addressed this subject: Kh. M. Loparev, D. I. Sapozhnikov, P. S. Smirnov, I. Ya. Syrtsov, P. N. Miluikov, M. B. Pluikhanova, A. V. Borodkin, A. T. Shashkov, N. S. Demkova, E. M. Yukhimenko and many others. Recently two books by historians E. V. Romanova ${ }^{1}$ and

(*) This research has been financially supported by the Strategic Development Program of Petrozavodsk State University for the years of 20122016.

Abbreviation list:

БАН - [LRAS] Library of the Russian Academy of Sciences (St. Petersburg)

ГИМ - [SHM] State Historical Museum (Moscow)

ИР ЛИ - [IRLI] The Institute of Russian Literature (The Pushkin House)

(St. Petersburg)

PНБ - [NLR] National Library of Russia (St. Petersburg)

ТО $Д \mathrm{P} \Lambda-[W D O R L]$ Works of Department of Old Russian Literature at IRLI

(1) Е. В. РОмановА, Массовые самосожжения старообрядиев в России в XVII-XIX векаx [Mass Self-Immolations by the Old Believers in Russia from the Seventeenth Century to the Nineteenth Century], Санкт-Петербург, 2012. 
M. V. Pul'kin ${ }^{2}$ have been published about the Old Believer selfimmolations, which is a sign of abiding interest in this topic. The main corpus of the Old Believer writings about self-immolations and other 'suicidal deaths' has also been reflected in scholarly research. However, some gaps remain which are going to be discussed shortly.

First, let's recall some well-known facts. At the end of the seventeenth century the Russian Old Believers were split into two groups - apologists and strong opponents, over the issue of suicide as a form of salvation from the Antichrist. Both of them had to provide ideological justifications for their views and in search of their arguments referred to the Holy Scriptures, writings of the Church Fathers, dogmatic theology and hagiography. Thus, this controversy initially was theological and basically based on interpreting different ancient sources. Protopope Avvakum, the author of Epistle to a Brother, Epistle to Simeon and Conversations about Abraham (let's not discuss the question of authenticity of these works here ${ }^{3}$ ), is widely regarded as one of the first theorists of 'the suicidal death'. In 1691, apparently in Pomor region, monk Euphrosine, hegumen Dosifey's disciple, wrote an extensive treatise against self-immolations Parrying Writing which survived in a single copy. ${ }^{4}$ According to N. S. Demkova, the sources of this work are The Moaning by the Pomor elders, excerpts from Patristic writings and a sermon against self-immolation - all of them preserved in the content of the so-called Kizhi Codex. ${ }^{5}$ At the end

(2) М. В. ПулькиН, Самосожжения старообрядцев (середина XVIIXIX в.) [The Old Believer Self-Immolations (from the Middle of the Seventeenth Century to the Nineteenth Century)], Москва, 2013.

(3) About these works and the problem of their authenticity see: POMAнова, Массовые самосожжения старообрядиев, с. 105-111.

(4) Отразительное писание о новоизобретенном пути самоубийственных смертей. Вновь найденный старообрядческий трактат против самосожжения 1691 года. Сообщение X. Аопарева [Parrying Writing about the Newly Invented Way of Suicidal Deaths. The Old Believer Refound Treatise against SelfImmolation (1691). Kh. Loparev's paper], Санкт-Петербург, 1895.

(5) Н. С. ДЕмКОВА, “Из истории ранней старообрядческой дитературы. V. «Жалобница» поморских старцев против самосожжений (1691 г.)" [From the History of the Old Believer Early Literature. V. The Moaning by the Pomor Elders against Self-Immolations (1691)], in: Древнерусская книжность. По материалам Пушкинского Дома [The Old Russian Booklore. The Pushkin House Materials], Пенинград, 1985, с. 48-61. About The Kizhi Codex and its writings against self-immolations also see: Памятники книжной старины Русского Севера: коллекици рукописей XV-XX веков в государ- 
of the seventeenth century and in the first quarter of the eighteenth the founders of the Old Believer Vyg community Daniil Vikulin, Peter Prokop'ev and Simeon Denisov made a stand for self-immolations; their position on this issue was expressed in Peter Prokop'ev's Message to Daniil Vikulin (see further) and in Simeon Denisov' story about the Siberian sufferers. ${ }^{6}$

A compilation of hagiographic texts justifying suicides is already contained in Epistle to a Brother by Protopope Avvakum (or PseudoAvvakum). ${ }^{7}$ Its author cites examples from ancient Acts of the Martyrs about saints who had to commit suicide in front of their torturers in order to save their faith and chastity. He interprets the suicides of his coreligionists as a repeat of those heroic deeds and refers to the Lives of St. Solomonia (August 1) from the Old Testament, martyrs Drosis (March 22), Domnina (October 4), Ennatha (November 13), Arethas (October 24) and to the 'Priklad' (exemplum) about Roman prefect's wife Sophronia from Velikoe Zertsalo (The Great Mirror). ${ }^{8}$ In oral preaching and not extant writings the apologists cited the names of Venerable Mark the Anchorite of Athens, St. Simeon Stylites, St. Theodore of Amasea, Philoneides and other saints. ${ }^{9}$ Later some of these examples were repeated by Peter Prokop'ev and Simeon Denisov.

Criticism of these arguments is contained in Euphrosine's Parrying Writing. In a nutshell, its points are the following. Firstly, according

ственных хранилищах Республики Карелия [Old Manuscripts of the Russian North: XV-XX Century Collections in State Depositories of the Republic of Karelia], сост., отв. ред. и автор пред. А. В. ПигиН, Санкт-Петербург, 2010, c. 293-300, 462-487.

(6) Seе: А. И. МАльЦЕВ, “Неизвестное сочинение С. Денисова о тарском «бунте» 1722 г." [Unknown S. Denisov's Writing about 1722 Tarsky Riot], in: Источники по культуре и классовой борьбе феодального периода [Sources on Culture and Class Struggle of the Feudal Age], Новосибирск, 1982, c. 224-241.

(7) The text is published in: Материаль для истории раскола за первое время его существования, издаваемые братством св. Петра митрополита [Materials for the History of the Raskol at the Beginning of its Existence, Published by Metropolitan St. Peter's Brotherhood], под ред. Н. СуББОтИНА, Москва, 1887 , т. 8 , с. $67-81$.

(8) Sее: О. А. ДЕРЖАВИНА, «Великое Зерияало» и его судьба на русской почве [Velikoe Zertsalo and its Fate on Russian soil], Москва, 1965, с. 205.

(9) Seе: Отразительное писание, с. 019, 021, 13, 14, 44, 82-84 and other. 
to Euphrosine, his opponents deliberately distorted facts of some Lives, e. g. Mark the Anchorite of Athens and Simeon Stylites didn't commit suicide, but the Lord «Марка промыслом Божиим во Фракию принесе, а Симеона анггел Господень подхватя, жива на землю постави» 'brought Mark to Thrace by divine providence and the Angel of God caught Simeon and put him on land alive. ${ }^{10}$ Secondly, suicides of some saints were condemned even in ancient times. Euphrosine provides an example of St. Philoneides who, fearing torment, covered his head with a kerchief and jumped from a high place onto earth. The Church Fathers at a synod condemned his suicide, «конец бо не благ получи, несть бо Божие дело сотвори» 'since his end was not to the good and it was not the will of God.'11 Thirdly, the apologists too widely interpreted suicide as any voluntary decision to suffer in the name of Christ. The choice of death for the sake of faith that a man of free will makes, is not suicide. Otherwise Christ voluntarily undergoing suffering 'for our sake' would have been considered a suicide victim. ${ }^{12}$ Fourthly, and Euphrosine repeats this idea many times, ancient suicides of saints are 'smotritel'nye veshchi' (permitted by God because of His mercy on weak human nature), that is utterly exceptional, beyond canon law, but nevertheless excused by the Lord since God works in mysterious ways. These 'smotritel'nye' cases belong to the realm of miracle, Providence, and therefore they mustn't be followed. ${ }^{13}$

Probably at the very end of the nineties in the seventeenth century Peter Prokop'ev, a ecclesiarch ('ustavshchik') from the Vyg community, addressed the issue of 'suicidal death.' ${ }^{14}$ Undoubtedly, he was acquainted with Euphrosine's Parrying Writing or at least with the arguments contained in his text. The Message represents a response to Daniil Vikulin's question about acceptance of 'suicidal death' and contains a number of excerpts from lives of saints.

(10) Отразительное писание, с. 14.

(11) Ibid., c. 116.

(12) Ibid., c. 88.

(13) Ibid., c. 35, 47, 48, 56, 69 and other. Euphrosine's reasoning about 'smotritel'nye veshchi' is based on Taktikon by Nikon of the Black Mountain.

(14) About Peter Prokop'ev see: Н. В. ПоныРко, "Петр Прокопиев," in: Словарь книжников и книжности Аревнеи Руси [The Dictionary of Ancient Rus Scribes and Booklore], вып. 3, ч. 3, Санкт-Петербург, 1998, с. 34-35. 
Paradoxically, despite the researchers' keen interest in the history of Old Believer self-immolations, the Message, one of the main sources for this topic, actually remains unexplored. It was published in 1909 by P. S. Smirnov ${ }^{15}$ and usually researchers cite this publication without reference to the manuscripts.

The suggested textual study of this writing is done on the basis of 10 copies dating back to the eighteenth and nineteenth centuries. Obviously, the manuscript tradition of the Message is richer, but some preliminary conclusions can be already drawn. The Message has survived in two main editions - I will refer to them as The Initial edition and The Extensive one. The Initial edition exists in 5 copies: ${ }^{16}$ this very edition published by P. S. Smirnov reproduces the NLR copy, Q.XVII.200 including textual variants taken from 3 other copies. It should be noted that the NLR copy, Q.XVII.200 is late, dating back to the end of the eighteenth century; probably, the publisher chose it because it is of Vyg origin and includes different writings of Pomor authors. ${ }^{17}$ The earlier copy of the Initial edition is contained in a manuscript from Druzhinin's collection in LRAS, № 462 (491). It dates back to the thirties and forties of the eighteenth century and is a part of the codex which also contains Vyg community writings, one of them (Andrew Denisov's Sermon on the Antichrist) is copied by Peter Prokop'ev's hand. ${ }^{18}$ The very copy of the Message is written by

(15) П. С. СмиРнов, Споры и разделения в русском расколе в первой четверти XVIII века [Disputes and Separations in Russian Raskol in the First Quarter of the Eighteenth Century], Санкт-Петербург, 1909, с. 081-088.

(16) БАН, собрание Дружинина [LRAS, Druzhinin's collection], № 462 (491), л. 209-216 об., 1730-1740-е гг.; БАН, собр. Никольского [LRAS, Nikolsky's collection], № 68, л. 290-302, 1760-1780-е гг.; РНБ [NLR], Q.XVII.200, л. 241-243 об., конец XVIII в.; РНБ [NLR], собрание Вяземского [Vyazemsky's collection], О. № 6, ^. 187 об.-197, XVIII в.; РНБ [NLR], O.I.443, 九. 407413, XIX в.

(17) See the description of the manuscript in: И. А. БЫЧКОВ, Каталог собрания славяно-русских рукописей П. Д. Богданова [Catalog of Slavic-Russian Manuscript Collection], Санкт-Петербург, 1893, вып. 2, с. 145-159. The Message recently published by M. V. Pul'kin is a reprint of this copy (ПульКИН, Самосожжения старообрядиев, с. 272-276).

(18) See the description of the manuscript in: Сочинения писателейстарообрядиев первой половины XVIII века [Works by Writers-Old Believers in the First Half of the Eighteenth Century], сост. Н. Ю. БуБНОв, Санкт-Петербург, 2001, с. 272-276. 
Vyg scribe Evsei Ermilov (died in 1748). ${ }^{19}$ Both the content of this edition and its inclusion in $\mathrm{Vyg}$ community codices unequivocally indicate that it is primary.

The Extensive edition is also known in 5 copies dating from the second half of the eighteenth and nineteenth centuries. ${ }^{20}$ Evidently, this edition was put together after Peter Prokop'ev's death (died in 1719), but unlikely before the middle of the eighteenth century. The unknown editor of this edition made the following changes: firstly, he combined those extracts from the Initial edition, where the author addresses Daniil Vikulin and reflects on the topic of suicide; secondly, he placed most examples of suicide in some kind of appendix to this Message. In some copies this appendix has a separate heading «О самоубийственной яже за благочестие бывающей по нужде при нашествии гонителей страха ради не стерпех муки, и яко сице умирающии с мучениками причтени бывают» 'About suicidal death committed for the sake of piety - this death sometimes can be a necessary measure, since some pious men fear that they are not able to bear torture in case of invasion of their persecutors and in order not to betray their faith, they commit suicide. Such men can be numbered among martyrs' (ИРАИ, Северодвинское собрание [IRLI, Severodvinsk collection], № 137, л. 309; и др.) ог «Свидетелства от Святаго Писания о самоубийственной смерти яже за благочестие веры святыя, бывающей по нужды при нашествии от гонителей страха ради и от нестерпимых мук за немощь боящеся отпадения, яко сице умирающеи с мученики причтени бывают» 'The Holy Scriptures testimonies to suicidal death for the sake of preserving piety - these suicides can be a necessary measure, since some men fear that they are not able to bear intolerable torture brought by oppressors and persecutors of the holy faith, and under torture may abandon their faith. For this reason they commit suicide.

(19) I thank E. M. Yukhimenko for the help with attributing the handwriting.

(20) ИР ИИ, Карельское собрание [IRLI, Karelian collection], № 34, л. 5-36 об., последняя четверть XVIII в.; РНБ, собрание ОДДП [NLR, OLDP collection], О. 130, л. 175-188 об., 1760-1770-е гг.; ИР ИИ, Северодвинское собрание [IRLI, Severodvinsk collection], № 137, л. 307 об.324 об., последняя четверть XVIII в.; ИРЛИ, коллекция АмосоваБогдановой [IRLI, Amosov-Bogdanova's collection], № 32, ^. 247-255 об., 1780-е гг.; БАН, собрание Дружинина [LRAS, Druzhinin's collection], № 256 (303), л. 223 об.-233, 1860-е гг. 
The dying in such a manner can be numbered among martyrs' (ИР ЛИ, колиекция Амосова-Богдановой [IRLI, Amosov-Bogdanova's collection], № 32, ^. 248 об.-249). Thus, the Extensive edition consists of two parts: it combines the abridged version of Peter Prokop'ev's original text with the article "About the Suicidal Death..." which also demonstrates a clear connection with the Initial edition of the Message. Another important feature of the Extensive edition is the significant increase of extracts about the topic of 'suicidal death' from different books. The Initial edition contains 13 examples of this kind, but in different copies of the Extensive edition they fluctuate between 28 and 31. The third significant difference is that in the original text Peter Prokop'ev clearly distinguishes between death in the name of faith and death for the sake of preserving chastity, but in the later edition all examples under the heading '....about death... for the sake of piety' are generally interpreted as suicides in the name of faith. Finally, the editor of the Extensive edition treats the concept of suicide wider than it is done in the original text: for example, he cites an extract from the Prologue famous legend (October 7) about a goldsmith from Alexandria who poked his eye out in order to overcome his sexual lust. The copies of the Extensive edition contain its several versions, but I'm not going to deal with this subject in this article.

Let's consider those examples of 'suicidal death' which were included in the Extensive edition. Out of 13 excerpts from the Initial edition 11 were included in the Extensive one; excerpts from the Lives of St. Martinian the Righteous (February 13) and St. Joannicius the Great (November 4) were excluded. Other 20 examples were added by the editor. Among them only two examples - about martyr Philoneides (August 30) and the Forty Martyrs of Sebaste (March 9) - had been discussed earlier in Old Believer literature, Euphrosine mentions them and gives comments. All other extracts are apparently new and indicate that the editor intentionally searched for such material in books. Excerpts come from different sources: the Lives of Saints with references to the Prologue and the Menaion, works of Russian historiography, the Lausiac History, the Revelations of Methodius of Olimpus, the Blessed Monk Dorotheus's Tsvetnik (Flower-Bed), the Commentary on the Prophet Daniel by Hippolytus of Rome, the Triodion hymns and other books. In spite of such diversity of the sources, these excerpts are perceived as one homogeneous text, a martyrology, because they are merged together on the basis of their common subject of sainthood and suffering in the name 
of faith. The Initial edition contains only one example from the Russian source - the suicide of the Ryazan Princess Eupraxia in 1237 at the time of Batu's Khan capture of Ryazan, however, there are already six such examples in the Extensive edition.

An extract from the Life of Isidore of Yuryev in the Extensive edition provokes some thought on the question of hagiographic poetics of likening. Hagiographic topoi based on 'focusing on patterns' and poetics of imitation or likeness make up the foundation of hagiography. Recently they have increasingly attracted researchers' attention from theoretical point of view as well as in terms of hagiographic genre variations and because of the material used for some works. ${ }^{21}$ The gist of likeness principle in hagiography O. V. Panchenko defines as follows: «при изображении каждого нового святого агиограф (автор жития, похвадьного слова иди канона) находит соответствующий «агиодогический образец» среди великих подвижников древности, по подобию которого и изображает прославляемого им святого» 'when depicting every next saint the hagiographer (an author of hagiography, eulogy or canon) finds a corresponding 'hagiographic pattern' among great ascetics of the past in order to depict in the image of him the glorifying saint. ${ }^{22}$ According to the researcher's observations, likeness could be carried out in two ways - verbally and non-verbally - and by several features: identical names, similarity in asceticism type, similarity in social status etc. O. V. Panchenko considers in his article such cases when likeness of a saint to his/her hagiotype is done, so to speak, "inside" the text itself and the hagiographer is quite conscious of it. However, it should be

(21) First and foremost these are the researches by T. R. Rudi and O. V. Panchenko, see: T. Р. Руди, “Топика русских житий (вопросы типологии)" ["Topoi of Russian Hagiographies (Issues of Typology)"], in: Русская агиография: исследования, публикации, полемика [Russian Hagiography: Researches, Publications, Controversy], Санкт-Петербург, 2005, с. 59101; IDEM, “О композиции и топике житий преподобных" [“On Texture and Topoi of Lives of the Venerables"], ТО $Д Р \Lambda$, т. 57 (2006), c. 431-500; IDEM, "О топике житий юродивых" [“On Topoi of Lives of Blessed Fools"], ТОДРЯ, т. 58 (2007), с. 443-484; О. В. ПАНЧЕНКО, “Поэтика уПодоблений: (к вопросу о «типологическом» методе в древнерусской агиографии, эпидейктике и гимнографии)" ["Poetics of Likeness: on the Question of 'Typological' Method in Old Russian Hagiography, Epideictic Oratory and Hymnology"], ТОДРЯ, т. 54 (2003), с. 491-534.

(22) ПАНЧЕНКО, “Поэтика уподоблений," с. 491. 
noted that it is worthwhile to study cases of secondary likeness, when hagiographic plot is inherent in the content of some compilation and demonstrates connections to its other parts. At that, the initial likeness, explicit in the text of hagiography, is lost and the saint acquires in this compilation a new hagiotype.

The Life of Isidore of Yuryev from the Extensive edition provides an example of secondary likeness. It is a Russian martyrology of the sixteenth century narrating about the martyrdom of Russian clergyman Isidore and 72 residents of Yuryev-Livonian city (Tartu at present) in 1472. They were thrown under the ice of the river Omovzha by order of a local Catholic bishop for their refusal to convert to 'Latin faith ${ }^{23}$. The text survived in two editions, one of them, the distributed, was written by the famous sixteenth century hagiographer from Pskov Vasili Varlaam. It is this very edition from where the Message's editor of the Extensive edition makes an excerpt. After telling briefly the story of St. Isidore's death the Old Believer author borrowed from the text of Life the following episode: 'the godless Latins' brought to the frozen river a wife with a three year old infant in her hands. Then they took the boy from the woman and threw her under the ice. The infant: 'started squealing in the hands of the lawless and scratched their faces' («нача верескати на руках законопреступных и дица их драти»). When the lawless put the boy onto the ice he came up to the ice-hole, crossed himself three times, looked at the people around and uttered: «Ибо и аз християнин есмь верою в Господа моего Исуса Христа и хощу ту же смерть прияти, якоже и учитель наш великий Исидор» 'For I am a Christian and believe in Our Lord Jesus Christ I want to die as our great mentor Isidore died'. After these words he 'plunged into the river under the ice' («вержеся в реку под лед»). ${ }^{24}$

(23) See: А. В. СОКОлОвА, “Житие Исидора Юрьевского” [“The Life of Isidore of Yuryev"], in: Словарь книжников и книжности Аревней Руси [Тhe Dictionary of Ancient Rus Scribes and Booklore], вып. 2, ч. 1, Ленинград, 1988, c. 284-285; А. В. КузьмИН, “Исидор священномученик и 72 (73) мученика, Юрьевские, Аивонские" ["Holy Martyr Isidore and 72 (73) YuryevLivonian Martyrs"], in: Православная энцииклопедия [Orthodox Encyclopedia], Т. 27, Москва, 2011, с. 203-206.

(24) From here on in The Extensive edition of the Message is cited as in: ИРАИ, Карельское собрание [IRLI, Karelian collection], № 34, л. 5-36 об. See the corresponding place in the source: А. И. РОГОВ, "«Повесть об Исидоре Юрьевском» как исторический источник и памятник русской 
I. I. Fetisov devotes his article to the problem of the Life of Isidore of Yuryev literary sources. ${ }^{25}$ The researcher connects the abovementioned episode with Byzantine Life of Quiricus and his mother Julietta (July 15) who were martyred about the year of 305 in Tarsus under emperor Diocletian's rule. This analogy is obvious as it is clearly stated in the Old Russian text: «О дивстство, братие, тако Бог прославляет святыя своя, но и о сем убо отрочати, якоже и древле и о Кирике показа с материею его» 'Oh, miracle, brothers, how God praises His saints is shown at the example of this infant as well as the ancient Quiricus and his mother.' ${ }^{26}$ Thus, 'verbal' technique of likeness, as O. V. Panchenko calls it, is used in the text of the Life of St. Isidore - 'the hagiographic pattern' is specified clearly.

Indeed, the Life of Isidore of Yuryev and that of Quiricus and Julietta exhibit obvious parallels. Both infants are of the same age -3 , they witness the martyrdom of their mothers; when sitting on the knees of torturers or being held in their arms the infants scratch their faces and at that demonstrate untypical to their age courage and mind openly professing Christianity in front of their enemies. However, the significant difference is that the boy from Yuryev throws himself into the ice-hole, whereas Quiricus's death is depicted in a more traditional for martyrology manner - he gets killed by his torturer. Evidently, the motif of suicide in the story of the three-year-old Yuryev martyr wasn't relevant for the Pskov hagiographer, otherwise he would have selected a different 'hagiographic pattern' among saint child martyrs.

Images of child martyrs can be found in various works of Early Christian hagiography: these are children who refused to make sacrifices to pagan gods and perished together with their parents, children victimized by their pagan parents, and children who were victims of dynasty killing. The review of these writings and analysis of certain

публицистики периода Дивонской войны” ["Tale of Isidore of Yuryev as a Historical Source and Text of Russian Political Essays during the Livonian War"], in: Славяно-германские культурные связи и отношения [SlavicGerman Cultural Connections and Relations], Москва, 1969, с. 326-327.

(25) И. И. ФЕТИСОВ, “К дитературной истории повести о мученике Исидоре Юрьевском" [“On Literary History of Story about the Martyr Isidore of Yuryev"], in: Сборник статей в честь акад. А. И. Соболевского [Collection of Articles in Honour of Academician A. I. Sobolevsky], Пенинград, 1928 , c. $218-221$.

(26) РОГОв, “Повесть об Исидоре Юрьевском,” с. 326. 
cults is presented in studies by American researcher P. H. Wasyliw and in A. A. Panchenko's book about wonderworkers from Menyusha village. ${ }^{27}$ Probably, it is worth noting, topos 'the saint is immature in terms of age but possesses mature mind' is characteristic of some hagiographic writings, which share this feature with partly folklore works about a wise infant such as the Tale of Basarg and Borzosmysl or the Tale of King Solomon's Birth and Adventures.

The tale of the Yuryev boy, included in the Old Believer compilation about the subject of 'suicidal death', has, strangely enough, a much closer sacred precedent in the Life of St. Arethas, the leader of the Christian community of Najran in Arabia, who was killed by Jews in the sixth century. The Life of St. Arethas entered the Prologue collection, the Great Menaion Reader and the late Menaion for October 24. In the Extensive edition of the Message there is one more story about an infant martyr containing the abovementioned topoi: a Christian woman's son was thrown into the fire because he had refused to recant Christ. He is only 4 years old, like 'a sheer babe' he climbs up upon the knees of King of the Jews, but like 'an adult possessing mind' professes his faith: «Поистинне Христа люблю» 'I verily love Jesus.' When the King gives an order to one of his princes to teach the infant "the sheeny law" («закону жидовску»), he breaks away from the hateful and throws himself into the furnace following his mother. It is noteworthy that in comparison to the Initial edition of the Message this episode in the Extensive edition is considerably expanded and narrated with the details contained in the excerpt from the Life of Isidore of Yuryev. No doubt the Old Believer author was aware of the correlation between these two texts: the perished infant in Najran in the sixth century is actually a hagiographic prototype of the Yuryev martyr. Placed in a different context, the episode from the Life of Isidore of Yuryev accumulated new hagiographic associations and the saint got a new hagiographic pattern.

The logic of creating such association-likeness in the Old Believer compilation differs from that of in hagiography. Retrospective is im-

(27) P. H. WASYLIW, Martyrdom, Murder, and Magic: Child Saints and Their Cults in Medieval Europe, New York et al., 2008; А. А. ПАНЧЕНкО, Иван и Яков - необычные святые из болотистой местности: «Крестьянская агиология» и религиозные практики в России Нового времени [Ivan and Jacob Unusual Saints from Marshland: "Peasant Hagiography" and Religious Practices in Russia of the Early Modern Period], Москва, 2012, с. 186-192. 
portant for a hagiographer, he goes from the present to the past, finds a precedent in ancient history, whereas the Old Believer author moves in the opposite direction: the early Christian pattern is already given in the Initial edition, that is why the new excerpt about the Yuryev infant is introduced into the text as its repeat, "echo." This logic of aligning likenesses on the principle of perspective - from past events to later ones - finds an explanation in the controversy over the question of 'suicidal death' which aroused at the end of the seventeenth century and the beginning of the eighteenth. Suicide opponents claimed suicides 'for the sake of good faith' («благоверия ради») could be acceptable only in ancient times in the age of persecution, 'but at present it is inappropriate' («а ныне сему не достоит быти») - Peter Prokop'ev cites this opinion in the Initial edition. ${ }^{28}$ In response to his opponents he writes that he didn't find such statements in the Holy Scriptures: «И есть $л и$ где в божественном Писании запрещено о сих и который собор отверже таковая, или кто от святых возбрани сему быти? Но аще и многотрудне поищеши, и не обрящеши» 'Is it (suicide) forbidden somewhere in Scripture or was it denied at a synod, or maybe some saint prohibited it? No. Even if you search hard, you will not find it'. Peter Prokop'ev agrees suicides 'for the sake of piety' («благочестия ради») cannot be accepted norms, but they relate to 'smotritel'nye veshchi' and may be permitted «егда таковое же наидет время» 'when such times come' - in other words, when the times of persecution, as those in the early centuries of Christianity, recur. Peter Prokop'ev considered his epoch to be such time.

Despite the fact that the Initial edition contains an example from Russian history - Ryazan Princess Eupraxia's suicide, this work doesn't demonstrate the author's intention to provide national historical perspective of 'suicidal death' in Russia from the ancient times to the present day. The editor of the Extensive edition of the Message tried to fill this gap in the work of his predecessor. Apart from the discussed episode from the Life of Isidore of Yuryer, he included a piece from the Life of Olga of Kiev and three extracts from works of Russian hagiography. They all also have analogies in those translated texts which are a part of this edition and appear to be their Russian likenesses.

(28) The Initial edition of the Message is cited as in: СМИРНОВ, Сnops $u$ разделения, с. 081-088. 
The motif of readiness to commit suicide in order to preserve chastity is developed in the narrative about Olga of Kiev. Prince Igor is going hunting to Pskov land and he asks Olga who he sees for the first time to take him to the other bank of the river in a boat. During the crossing Prince Igor is looking lustfully at Olga, she guesses what is on his mind and addresses him with words of reproach, expressing readiness to jump into the river if he tries to fulfill his cunning plans: «...да приимет мя глубина сея реки, да не буду тебе на соблазн, и сама поругания угонзну» 'let the depth of this river take me and I shall drown. Shall I not be for your temptation and abuse'. The text is written with reference to the Menaion (July 11), most likely it is taken from the Vyg Menaion or from Monthly Readings (the lives of Russian saints) by Dimitry of Rostov, although it is of an earlier origin. ${ }^{29}$ Finding a fiancée during hunting, crossing the river, symbolically conveying the idea of marriage - these are traditional motifs of wedding ceremony and laments, which in the Life of Olga of Kiev are interwoven with the hagiographic motif of maiden's suicide as she is afraid to be raped, however, the latter motif is significantly reduced and presented only as a hint. In the Life of Olga of Kiev her hagiographic prototype is not named, but in the Old Believer compilation this image is perceived as "reflection" of numerous saints - ancient "adherents of chastity": Pelagia, Lucian's of Antioch disciple, who jumped out of a high window to her death, 'shall not her virginity be raped' («да не насидовано будет девство ея»), Roman prefect's wife Sophronia, who cut herself to death refusing to become Emperor Maxentius' victim, and a maiden from the Lausiac History, kidnapped by Persians, who tricked the lustful prince into cutting her head off - to name but a few.

Excerpts from historiographical writings with references to the Russian Chronograph, "drevniy Letopisets" (ancient Chronicle) and The Book of Degrees of the Royal Genealogy - about mass suicides during Batu's Khan invasion and Polish-Lithuanian intervention at the beginning of the seventeenth century - are repeats of alike stories from

(29) See the parallel place in the Vyg Menaion of the beginning of the eighteenth century: ГИМ, Музейское собрание II [SHM, Museum collection II], № 89, л. 189-190. About the work itself see: 3. А. ГрИЦЕнко, “Агиографические произведения о княгине Ольге" [Hagiographic Works about Princess Olga], in: Аитература Древней Руси [Ancient Russian Literature], Москва, 1981, с. 35-46. 
the Lives of Anthimus of Nicomedia, martyrs Drosis, Theodosia and Anastasia. Thus, the author fills fairly densely the historical distance between the ancient times and modern era with events from Russian history. Typically, extracts from Russian writings are concentrated in the final part of the text, although chronological principle is not maintained successively. It is worth noting that the author in his effort to create a Russian martyrology intentionally distorts the source text. For example, the story about the perish of Vladimir residents and Bishop Mitrophan in Theotokos Church in 1237 are interpreted as self-immolation, even though it is stated clearly in the chronicle that Tatars set the church on fire. ${ }^{30}$

The fact that the Extensive edition of the Message dates from the second half of the eighteenth century inevitably leads to the question of its goals. According to E. M. Yukhimenko's conclusions, attitude towards self-immolations in the Vyg community was not unchanging. At the early stage of the Vyg community history their members could accept forced 'fiery death' («огненную смерть») in the name of the old faith, however, in 1740-1750 they condemned self-immolations, this was reflected in particular in Vyg visionary literature aimed against the Filippovtsy. ${ }^{31}$ Self-immolation ideologists had no need of any theological arguments at that time. ${ }^{32}$ Apparently, historical precedents (Paleostrov, Kargopol and other 'burnings') were much more important for them. In this respect we can presume that

(30) Полное собрание русских летописей [Complete Collection of Russian Chronicles], т. 25: Московский летописный свод конияа XV века [Mоsсош Chronicle of the End of the Fifteenth Century], Москва, Ленинград, 1949, с. 128.

(31) См.: А. В. ПигиН, Е. М. ЮхимЕНКО, “К истории жанра видений в выговской литературной школе («Видение некоей старухи» в 1748 г.)” ["On the History of Genre of Dream Vision in the Vyg Literary School"], in: Выговская поморская пустынь и ее значение в истории России: сборник научHolx cmameŭ u материалов [Pomor Vyg Secluded Monastery and its Role in History], Санкт-Петербург, 2003, с. 132-133.

(32) Compare with the E. V. Romanova's conclusion: «Со временем, когда необходимость в веской аргументации в защиту самоубийства отпала, проповедники самосожжений, если судить по следственным документам, отказались от подобного способа убеждения (т. е. от агиографических и богословских аргументов. - A. П.)» [Over time, as the need for a compelling argument in favor of suicide disappeared, preachers of self-immolations, judging by investigative documents, gave up this method of persuasion (i. e. hagiographic and theological arguments. - A. P.] (POМАНОВА, Массовые самосожжения старообрядиев, с. 111). 
the author of the Extensive edition carried out the search of 'suicidal death' examples in ancient writings not for reasons of causing active topical controversy, but because he had in this work some historical, "academic," so to speak, interest. 'Smotritel'nye' cases in hagiographic and historical writings were perceived, most likely, as evidence of diverse and unusual paths people tread to achieve sanctity.

\section{SUMMARY}

The article presents a scantily studied manuscript of the Old Believer writings from Vyg community - Peter Prokop'ev's Message to Daniil Vikulin (the end of the 1690s). The Message is dedicated to justification for 'the suicidal death' for the sake of saving faith and chastity, containing a number of excerpts from Byzantine and Russian hagiographic works about suicide of saints in antiquity. In the middle of the eighteenth century the original text of the Message was considerably revised by an unknown author, who added new excerpts. The article pays special attention to excerpts from Russian manuscripts from the Life of Isidore of Yuryev, the Life of Olga of Kiev, historiographical writings about mass suicides during Batu's Khan invasion and Polish-Lithuanian intervention at the beginning of the seventeenth century (with references to the Russian Chronograph, "drevniy Letopisets" (ancient Chronicle) and The Book of Degrees of the Royal Genealogy). Based on this material, the paper deals with the problem of "poetics of likeness" in hagiography. The inclusion of Russian martyrology in the context of Early Christian one as its natural continuation finds its explanation in the Old Believer national patriotic concept of destiny of Holy Russian and Moscow, the Third Rome, in the history of Orthodoxy. 